\title{
粘土懸濁液の摇変性の測定*
}

\author{
梅屋薰**
}

\section{Some Considerations on the Measuring Method of the Thixotropic Properties of Some Clay Slips}

by

\section{Kaoru UMEYA}

(The Institute for Chemical Research, Kyoto University, Takatsuki, Osaka)

Two measuring methods are mainly used to obtain the thixotropic properties of clay slips. One of these is the method to measure the thixotropic properties by the stress decay, ${ }^{1}$ and the other is the hysteresis loop method. ${ }^{4)}$

The author has already reported the results obtained through the stress decay method, ${ }^{3)}$ and here in this paper, the results gained from the hysteresis loop method are reported.

The results obtained by this method indicate that

(1) the hysteresis area, that is, thixotropic behavior, of the clay slips, decreases exponentially with the increase of the water content.

(2) the hysteresis area, also, decreases exponentially with the increase of the amount of deflocculant quantity.

The thixotropic levels are decided by the method of the stress decay, ${ }^{1)}$ and the degrees of thixotropic behavior may be obtained by the hysteresis loops, ${ }^{4)}$ and yet no distinct relation has been found so far between the thixotropic levels and degrees of thixotropy. However, we are obtain the conversing constant between the two quantities experimentally. In this paper, this able to conversing constant are decided using several clay slips. (Received Mar. 2, 1961)

1. 緒

摇変性の測定法には種々あるが，粘土懸濁液におい て広く用いられているのは

（測定法A），せ九断速度を一定にした場合のせん断 応力の時間的な変化を測定する場合

（測定法 B)，いわ以る履歴曲線を測定して，その履 歴面積から摇変性を決定する場合

の二つの方法である。

報告者は測定法Aによって, 粘土懸濁液の摇変性を 測定する場合については，既に前報において報告して いるので，当報文においては測定法 Bによって摇変性 を測定するときに現われる濃度低存性ならびに解こう (翏)度依存性について観察を行ないたいと思う。なお， 最後のところにおいて両測定法の比較についても観察

* 原稿受付 昭和 36 年 3 月 2 日

** 正員 京都大学化学研究所
を行ないたいと思う。

\section{2. 測 定 法}

\section{(I) 測定機}

用いた測定機は島津製作所製の UR-1 型ュニバーサ ルレオメーターである (Photo. 1)。これは回転二重円 筒型の構成で, 外筒が回転するが回転数は 0 400 rpm の間連続的に変化さすことが可能である。せん断応力 は内筒のねじれから求められる。検液部の温度は 250 ${ }^{\circ} \mathrm{C}$ まで可能であるが，当測定では $30^{\circ} \mathrm{C}$ に固定した。

\section{(II) 測定試料}

試料粘土は，粘土工業において可塑剤の主体をなし ている猿投木節粘土の中枝下木節粘土を用いた。枝下 木節粘土には高級陶磁器用としての上級粘土と, 一般 耐火物用の下級粘土とがあるが，測定は両者について 行なった。

粘土原磺をフレットミルで粉砕した後， $25 /$ 寸の傾 
斜ふるいを用いて選別したものを原料粉体とした：原 料粉体を家庭用電気ミキサー $(1.5 l$ 内容) の中に大れ， これに可塑水と解こう剤を加えて混練し泥しょうとし たものを，調製後 2 昼夜後に測定に供した。

調製泥しょうの濃度ならびに解こう度は Table 1 に示すとおりである，解こう剈としてモノケイ酸りー ダの水溶液老用いた，基礎とした水溶液の比重は $1 \cdot 27$ で,これを Table 1 に表示のcc数添加した. 添加量 $1 \mathrm{cc}$ は 0.5 (m.e. $/ 100 \mathrm{gr}$ 粘土)に相当する.

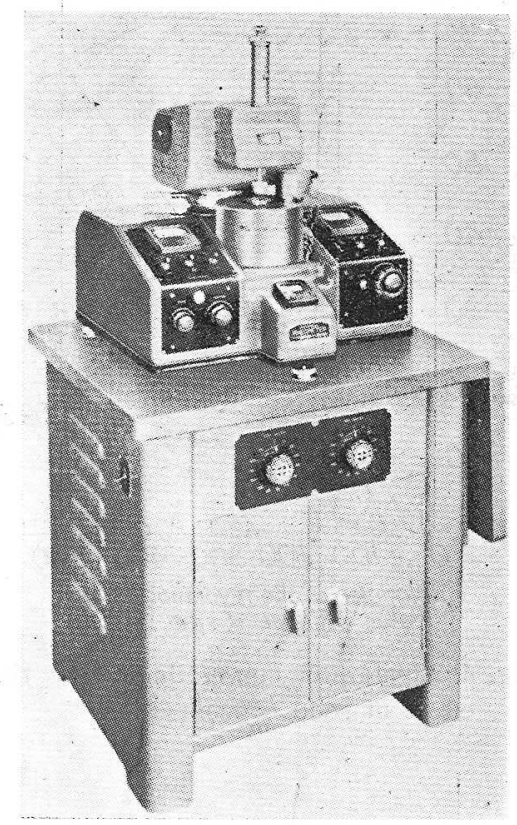

Photo. 1 Apparatus used; “Universal Rheometer, Type UR-I, Shimazu”,

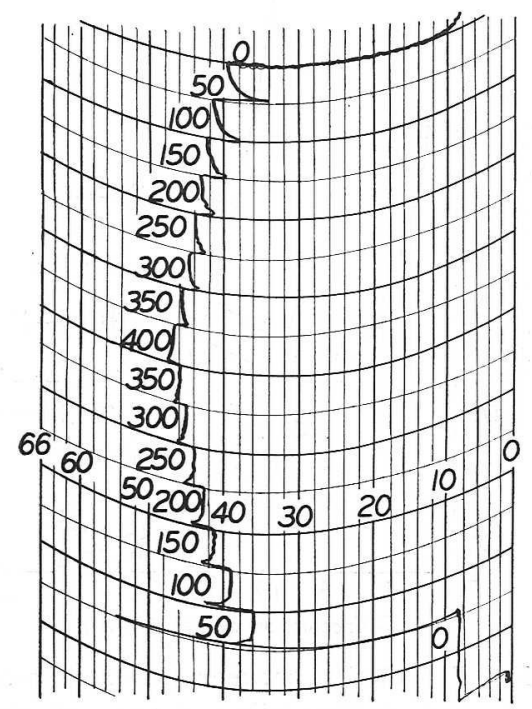

Fig. 1 Measuring chart

\section{3. 測 定 結 果}

用いた測定機により粘土泥しょうを測定すると,一 般に Fig. 1 に示す測定図形が記録板上に得られる。 図において縦軸は時間, 横軸は内筒のねじれ角（した がってせん断応力の大きさ）が示されている，測定は 時間の幅 $(\Delta t) 30$ 秒, 回転数の幅 $(\Delta d r / d t) 50 \mathrm{rpm}$, 最高 回転数 (T.R.) $400 \mathrm{rpm}$ で履歷曲線を描いた結果であ る. この曲線において回転数が変化した瞬間のねじれ 角の值を，そのときの回転数に対して目盛ると，一般 には Fig. 2 に示すような一つの環ができて，この環 は履歷曲線と呼ばれている。履歴曲線は Pryce-Jones やGreen などによって摇变性の尺度として採用され てい, 1)

Table 1 Relation indicating the solid concentration and the deflocculation degree of sample slips

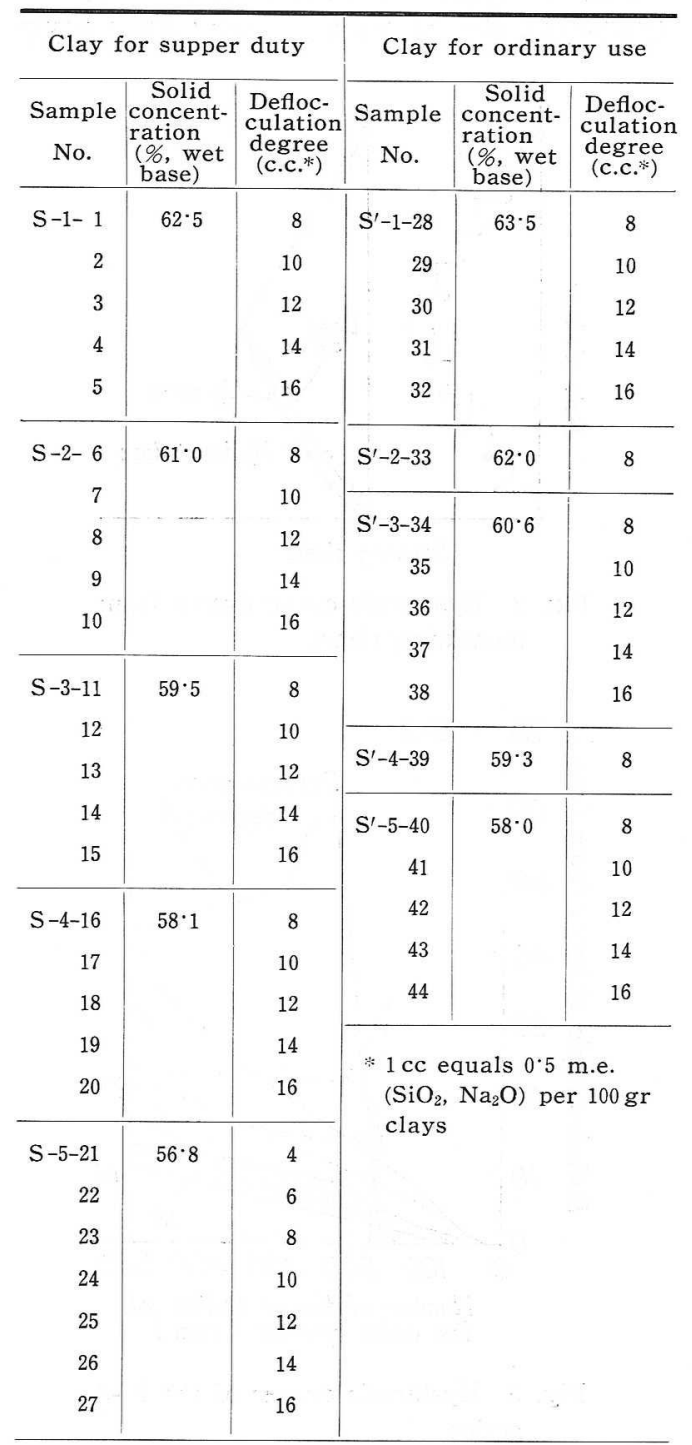




梅剭薰

今例として Table 1 に示した 44 種の泥しょうの中 から， S'-3に属する5 種類の泥しょう，ならびに $\mathrm{S}^{\prime}$ 采 列において解こう度 $8 \mathrm{cc}$ に相当するものを選び出して, 履歴曲線の測定結果を示すと Fig. 3,4 が得られる。 同様の測定を残りの泥しょうについても行ない，その 後で履歴面積の測定にあたるわけであるが，そのため にはなるべく一様な厚さを持った厚手の紙に図形を写 し，切り取って化学てんびんにより重量を測定した.

Fig. 5, 6, 7 の縦軸に示した価はそのときの重量を直 接に示したものである. Fig. 5 は上級粘土, Fig. 6 は 下級粘土にういての価である。

\section{4. 結果の検 討}

Fig. 7 は Fig. 5, 6 を基礎として履歴面積の水分依 存性の模様を示すように点経しなおしたものである。 上級粘土についても，下級粘土についても水分依存性 の形は多くの研究者によって研究されているように， 大体指数関数形で表わされる.この際上級粘土と下級

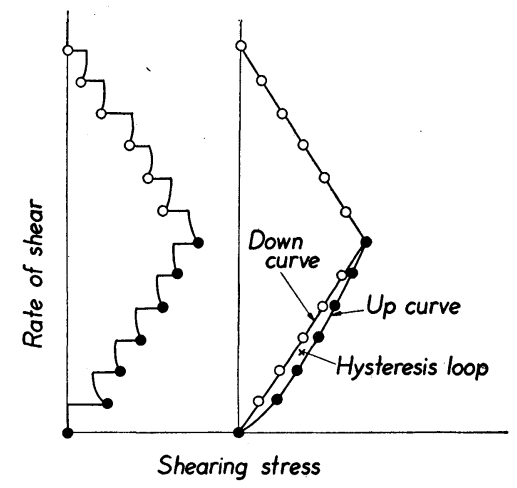

Fig. 2 Hysteresis curve drawn from measuring chart

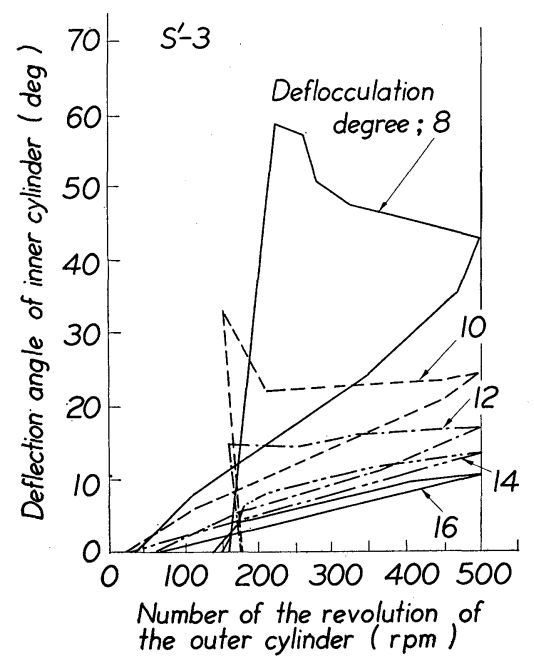

Fig. 3 Hysteresis curves of the $S^{\prime}-3$ series
粘土の区別は観察上に現われない，上級粘土は高級陶 磁器用に, 下級粘土は主として耐火物用にと使い分け

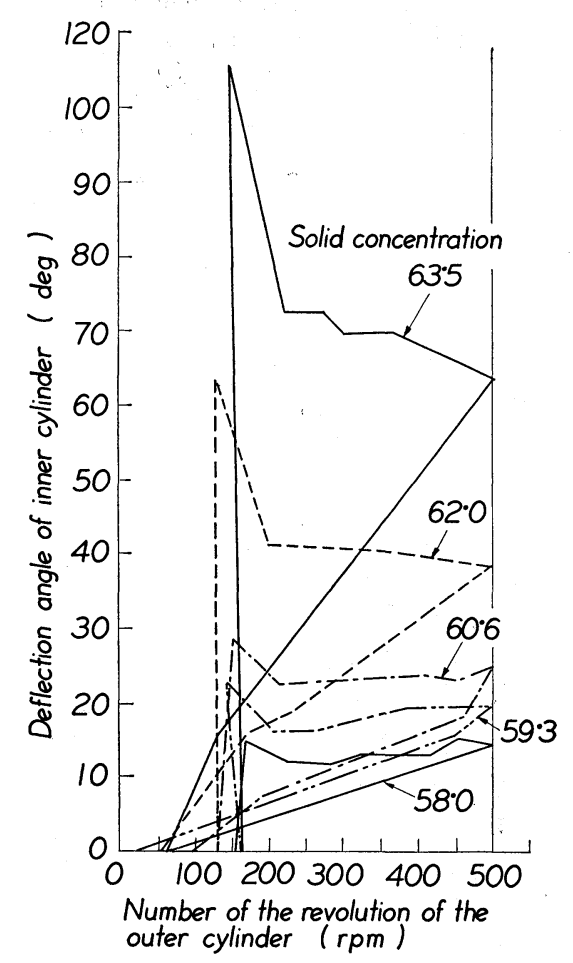

Fig. 4 Hysteresis curves indicating the effect of solid concentration

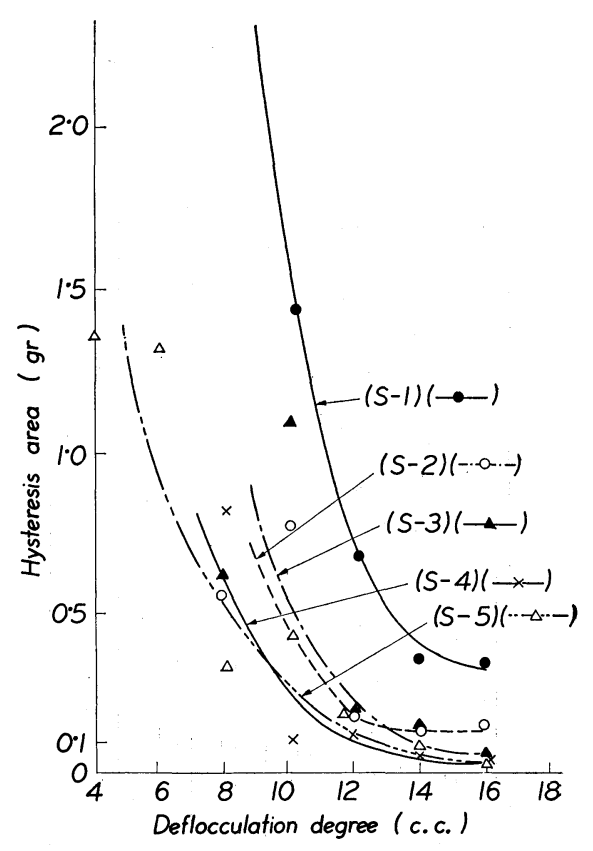

Fsg. 5 Relation between hysteresis area and deflocculation degree of the samples, S-series 
られているが，それらの摇変挙動には明りょうな区別 は検出できない.

解こう度が増加する場合の摇变性の挙動もやはり指 数関数形である (Fig. 5,6). 低下の仕方は水分が増加 するほどゆるやかである。したがって摇変という面か ら(現場的には鋳込みにおける造形性の面から)泥しょ うを考察するとさには，濃い泥しょうより薄い泥しょ うを使用するほうが制御は容易である。もちろんこの

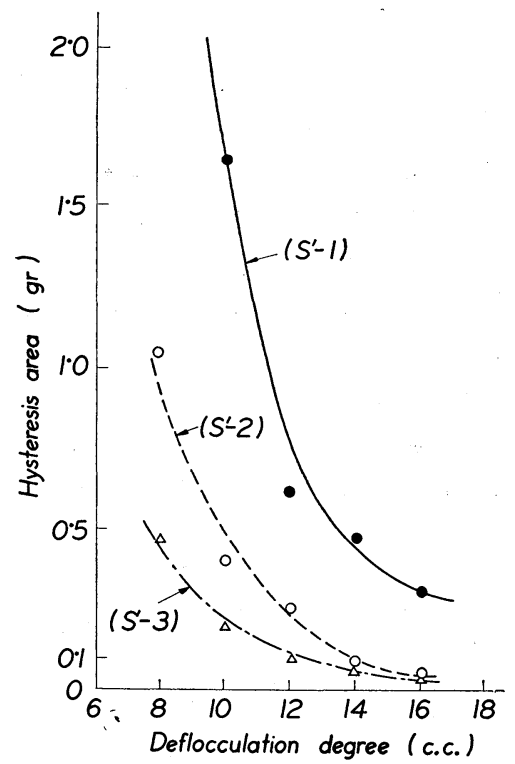

Fig. 6 Relation between hysteresis area and deflocculation degree of the samples, $\mathrm{S}^{\prime}$-series

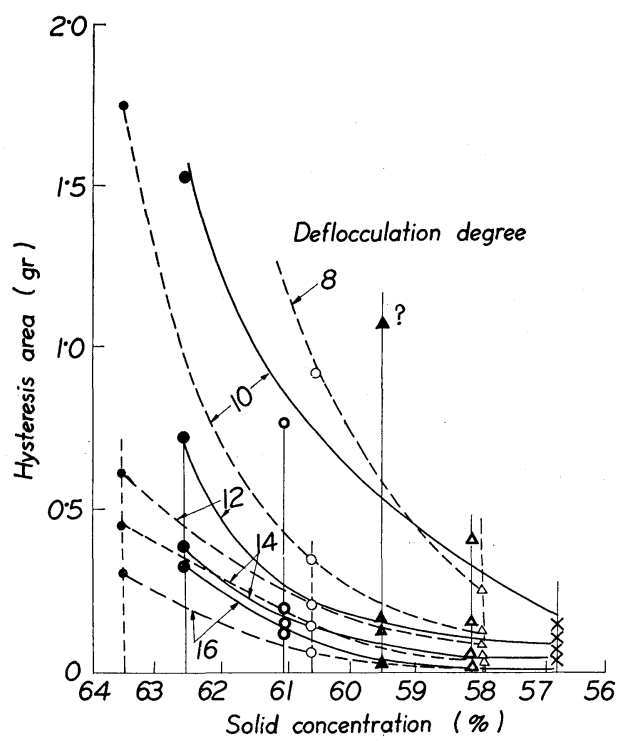

Fig. 7 Relation between hysteresis area and water content of both series
ことは泥しょうに要求される他の面たとえば沈降性あ るいは鋳込成形時の脱型性の面からの要求とは矛盾す る。とにかく解こう剤をあまり多く加えると, 泥しょ うの摇変性は低下するものと考えねばならない.

報告者は前報において測定法A，すなわちせん断速 度を一定に保った際のせん断応力の時間的変化を測定 する方法により，粘土懸濁液について摇変性を測定し た. Fig. 8 はそのときの測定結果の一つであるが, 使 用粘土は枝下下級粘土, 解こう度は $8 \mathrm{cc}$, 固体濃度は $63 \cdot 5,62 \cdot 0,60 \cdot 6,59 \cdot 3,58 \cdot 0 \%$ 種類である.この 図より粘性の值を算出し水分に対して目盛ると Fig. 9 の結果が得られる。図で $\eta(M)$ は瞬間応答 (摇変崩壊 前に相当)より, $\eta(E)$ は平衡応答(摇変崩壊後に相当) より決まる粘性である。いま各測定水分において

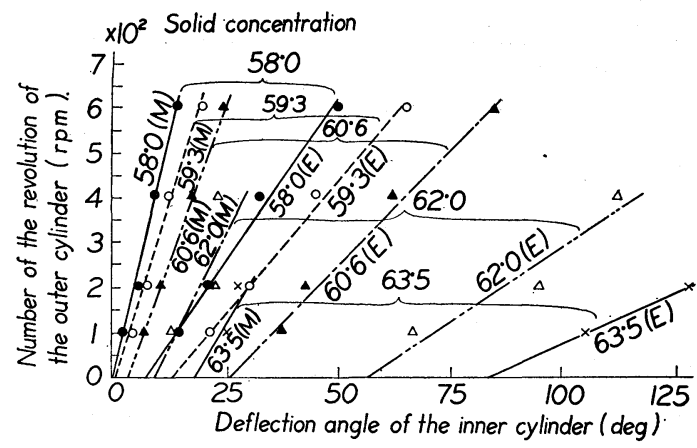

Fig. 8 Flow curves of the sample slips of the $\mathrm{S}^{\prime}$-series

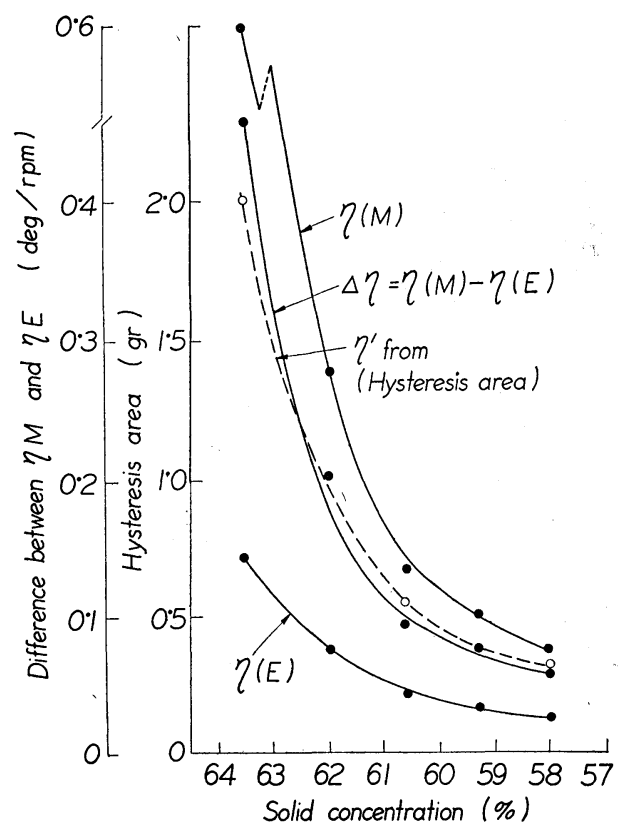

Fig. 9 Correlation between metbod $\mathrm{A}$ and method B 


$$
\Delta \eta=\eta(M)-\eta(E)
$$

の值を採り，これを Pryce-Jones の方法を踏襲して 摇変性の大きさを表わす数值と考えると， $\Delta \eta$ の水分 依存性は図示のように指数関数形を持ったものになる. なお，同図における $\eta^{\prime}$ の曲線はFig. 7 (10)の曲線す なわち測定法 B(前記)によって摇変性を決定したとき の関係から得られた履歴面積の水分依存性（下級粘土 についての值) を示すものである.これより Fig. 7 に おける縦軸 Sの值と Fig. 9 における縱軸（瞬間粘性 と平衡粘性の差） $\Delta \eta$ の間には次の関係が成立するこ とがわかる。

$$
\Delta \eta=5 S \frac{g_{r}(\mathrm{rpm})}{\mathrm{deg}}
$$

すなわち転換数は 5 である。この值は解こう度を変化 させた場合（添加量 $10 \mathrm{cc}, 14 \mathrm{cc}$ の場合のみを測定）に おいても，粘土を変化させた場合（技下上級粘土，な らびに瀬戸蛙目粘土の場合を測定）においても大体 5 の近くの価に収まった（これについては別に詳報する 予定である).

\section{5. 測定法 $\mathbf{A}$ と B との比較}

測定法 $\mathrm{A}$ も B も粘土泥しょうの摇変性を測定するに あたり，おもに用いられる方法であるが，そのうちA はまずせん断速度 $d r / d t$ を一定 $D_{1}$ にして, せん断応 力 $S$ の時間的な变化を追跡する. 次いで $D$ の值を $D_{2}$, $D_{3}$ と変えることにより測定值を採っていくわけであ る.これに反し $B$ は $\Delta(d r / d t)=\Delta D$ の值をまず $\Delta D_{1}$ に固定して, 測定時間間隔 $\Delta t=\Delta t_{1}$ の間測定を行ない， 次いで $\Delta D=2 \Delta D_{1}=\Delta D_{2}$ として時間間隔のほうは同 じ $\Delta t_{1}$ の間測定を行なう。次いで $\Delta D=3 \Delta D_{1}=\Delta D_{3}$ と してやはり $\Delta t_{1}$ 時間測定をしこのようなことを繰り 返して $n \Delta t_{1}$ の後に $\Delta D=n \Delta D_{1}=\Delta D_{n}$ （最高回転数 $T . R$.$) まで持っていさ，いわゆる上昇曲線を完成させ$ る. その後では時間の間隔 $\Delta t_{1}$, 回転数の幅 $\Delta D_{1}$ で下 降曲線在描く.上上昇曲線と下降曲線により履歴曲線が 構成される。この場合, 測定法 Aによるとさは変数は $D=d r / d t$ ただ一つであり，測定法 Bによるとさは $\Delta D, \Delta t, n \Delta D$ の三つが変数となりうる.

摇変性の特性とし 6 ( 測定の時間尺度はなるべく広く 採ることが望ましい.したがってどちらの方法を採用 するにしても，変数の範囲はなるべく広く採らねばな らない、すなわら摇变性を完全測定によって比較しよ うとすれば, 変数の範囲とその密度を大きく採らねば ならない、その場合, 変数が一つである測定法 $\mathrm{A} に よ$
るほうが，変数の多いB法による場合より簡便である. したがって摇変性を完全な姿で測定せんとする場合に はA法によるほうが推奖されるべきである。

しかし摇変性は必ずしも完全な姿において測定され るとはかぎらない，完全測定には変数の範囲も密度も できるだけ大きく採らねばならないので，多くの場合 手数がかかる。しかし近似の組成を持った泥しょうに おいては摇変性の完全測定を行なわないで， ある規定 した条件で測定した比較值を得るだけでも有用な場合 が多い，比較測定ではこのように変数をある規定され た条件に固定するので，その場合 A法によると一つの 変数 $d r / d t=D$ での測定值を基礎として判断を行ない， $\mathrm{B}$ 法によるとさは $\Delta D, \Delta t, n \Delta D$ の三変数を規定して 採った一つの履歷関係を基礎として判定を行なうわけ である．この場合は変数が多いということが利点とな って，B法による結果はA法による結果より多くの内 容を物語ってくれるのが常である。したがって簡便法 としては履歷曲線による測定が推奖されるべきである.

また，あらかじめ( 2 )式の变換定数を決めておくこ とにより, 両測定法の結果をある程度関係づけて考察 することも可能である.

\section{6. 結言}

（1）履歷曲線の方法(B法)によって粘土泥しょう の水分依存性と解こう度依存性を測定した。

（2）その結果と，もう一つの測定法であるA法に よって測定した值との比較を行なった.

（3）A法は摇変性の完全測定に，B法は比較測定 用に使い分けることが望ましいことを提案した。

（4） A 法での価をB法での価に転換する定数を二, 三の泥しょうについて決定した。

京大工学部纎維化学教室小野木重治助教授の御好意 により, 測定機の使用と, 使用についての御指導をい ただいた，上記の測定を完成できたのは一にその賜物 である。厚く謝意を表します。

\section{参考文 献}

1) Pryce-Jones, J., Koll. Zeit., 129, 96 (1952)

2) 梅屋. 材料試験, 9, 78, 164 (1960)

3) 沢井, 梅屋, 西川, 川本, 材料語験, 4, 27, 581 (1955)

4) Green, H., Industrial Rheology and Rheological Structures, p. 52 (1949)

5) Johnson, A.L., F.H. Norton, J. Amer. Cer. Soc., 25, 387 (1942)

6) 中川, 神戸, レオロジー-, 456 (1960)

7) 梅屋, 材料試験, 8, 70, 562 (1959) 